\title{
TECCIENCIA
}

\section{Comparison of the Behavior of biofuel based on Castor and Sunflower Oils}

\section{Comparación del comportamiento de biocombustibles basados en aceite de Ricino y Girasol}

\author{
Arnoldo Emilio Delgado ${ }^{1 *}$, William Aperador Chaparro², Jaime Parra Plazas ${ }^{3}$ \\ ${ }^{I}$ Escuela Colombiana de Ingeniería Julio Garavito, Bogotá, Colombia, articulopublish@gmail.com \\ ${ }^{2}$ Universidad Militar Nueva Granada, Bogotá, Colombia, william.aperador@unimilitar.edu.co \\ ${ }^{3}$ Escuela Colombiana de Carreras Industriales, Bogotá, Colombia, jparrap@ecci.edu.co
}

\begin{abstract}
This article presents the results of the comparison of two experimental studies to obtain biodiesel from castor and sunflower oils. During the development of the projects a standard methodology was adopted that defined the physical and chemical parameters of the biodiesel as a sunflower and Castor oil originated biofuel. To obtain a comparative model and maximize the performance of castor and sunflower oils, the NTC 100/04 standard was chosen, using the mix ratio 5,10, and 20\%, respectively, of biodiesel. Complying with the NTC 100/04 standard, the recommended parameters were followed in the tests performed to compare the results obtained. The methodology chosen allowed assessing the behavior of the combustion gases to achieve the final combustion composition, as well as the development of a comparison between the two biofuels with the fossil fuel (pure diesel) used in diesel engines in Colombia. This study was carried out in Bogotá (2600 $\mathrm{m}$ above sea level), and as a result there was a slight decrease in $\mathrm{CO}_{2}$ and $\mathrm{CO}$ output of combustion gases comparing the pure ACPM (oil fuel for engines) and the Biodiesel, for the various mixtures proposed under the ICONTEC norm.
\end{abstract}

Keywords: Biodiesel, Biofuel, Environmental Sustainability, Transesterification.

\section{Resumen}

Este artículo presenta los resultados de la comparación de dos estudios experimentales para obtener biodiesel a partir de aceite de ricino y girasol. Durante el desarrollo de los proyectos se adoptó una metodología estándar que permitió definir los parámetros físicos y químicos del biodiesel como biocombustible proveniente del aceite de girasol e higuerilla. Para obtener un modelo comparativo y maximizar el rendimiento del aceite de higuerilla y el de girasol se trabajó bajo la norma NTC 100/04, donde se utilizaron la relación de mezcla 5,10 y $20 \%$, respectivamente, de biodiesel. Cumpliendo con las normatividad de la NTC 100/04 se siguieron los parámetros recomendados en las pruebas realizadas para comparar los resultados obtenidos. La metodología utilizada permitió medir el comportamiento de los gases de combustión para obtener la composición final de la combustión y el desarrollo de una comparación entre los dos biocombustibles con el combustible fósil (diesel puro) que se utiliza en los motores diesel en Colombia. Este estudio se desarrolló a la altura de Bogotá ( $2600 \mathrm{msnm}$ ) y como resultado se determinó una leve disminución de $\mathrm{CO}_{2}$ y $\mathrm{CO}$ a la salida de los gases de la combustión entre el Aceite Combustible Para Motores (ACPM) puro y la mezcla de Biodiesel para las diferentes mezclas propuestas bajo norma ICONTEC

Palabras Clave: Biodiesel, Biocombustible, Sostenibilidad ambiental, Transesterificación

How to cite: Delgado A., Aperador-Chaparro W., Parra-Plazas J., Comparison of the behavior of biofuel based on castor and sunflower oils, TECCIENCIA, Vol. 7 No. 14., 54-60, 2013, DOI: http:/dx.doi.org/10.18180/tecciencia.2013.14.7 


\section{TECCIENCIA}

\section{Introduction}

The increase in motor vehicles year after year in Colombia has generated a direct relationship with environmental contamination due to constant gas emissions; additionally, Price variation of oil has permitted considerable increase in the demand of ACPM [1], to the point of displacing gasoline consumption for passenger and cargo transportation in developing countries, which is why it is necessary to have an alternative of a biodiesel using renewable resources.

Currently, some projects have been developed in Colombia to achieve clean production of biodiesel, which is a liquid hydrocarbon derived from plant and animal fats through a transesterification process based on the reaction of an oil or fat and an a half catalyzed alcohol [2].

Biodiesel has certain advantages compared to fossil diesel (oil). Some of these benefits include having non-toxic, biodegradable, as well as aromatic and sulfur-free fuels. Furthermore, its use notoriously lowers noxious gases from internal combustion engine exhausts by behaving as a fuel additive, thus, improving the amount of oxygen in the mix.

Biofuel production focuses on complying with the following variables: environmental sustainability, maintaining and increasing employment in the agricultural sector, energy self-sufficiency, agro-industrial development, improvement of the quality of fuels consumed in the country [3].

To produce biodiesel derived from castor oil, first, the oil is extracted from the seed, later, it is refined and the transesterification process is performed; the result of this process is glycerin, as well as the product of interest: biodiesel that can be used in pure form $(100 \%)$ in internal combustion engines or blended in any proportion with ordinary diesel of fossil origin.

The castor plant (Ricinus communis) is a good source for oil production; the plant is frequently used as base for resins, such as a lubricant for high-performance engines among other applications.

Sunflower oil is conventional oil mostly used for human consumption and it is obtained by pressing the plant's seeds (Helianthus annuus); technically it is a blend of unsaturated fats, although the oil generates high-impact pollutants [2].
The research was conducted in two stages: during the first stage, the biodiesel is obtained from the castor and sunflower oils and, in the second stage, the physicochemical properties of the biodiesel were determined in laboratory tests together with combustion tests on a diesel engine to evaluate its performance and compare it with petroleum-based diesel. Finally, a comparison was developed between castor and sunflower biofuels and fossil diesel.

\section{Experimental Work}

The experimental work was conducted in two phases, which include the characterization of castor oil and sunflower followed by determination of the physical-chemical properties of the biofuels obtained [4].

\subsection{Castor Oil}

\subsubsection{Phase One}

The first phase of the production process of biodiesel from castor oil was initiated by mixing methanol with sodium hydroxide as a catalyst, forming sodium methoxide $\left(\mathrm{Na}+\mathrm{CH}_{3} \mathrm{O}-\right)$ in an exothermic reaction, which was subsequently blended with the castor oil based on the mixtures B5, B10, and B20, according to the NTC 100/04 standard.

Then, infrared spectrometry tests were performed and were followed by performing the tests that determined the properties of pure biodiesel, as well as when blended with regular biodiesel at B5, B10, and B20; blends are made in percentage by volume, i.e., to obtain 1001 of B5, 51 of pure biodiesel $(5 \%)$ are blended with 951 of ACPM (95\%) [5] [6].

The heat of ACPM combustion, as well that of pure biodiesel and of the blends is also determined to observe its behavior by using a calorimeter pump [7] [8] [9].

\subsubsection{Phase Two}

In this phase, laboratory tests were performed for the biodiesel mixed with diesel fuel (ACPM), using a diesel engine coupled to an electric generator. This engine is characterized by certain operating parameters based on RPM schemes to facilitate comparison of the fuels. Coupled with a load generator, which allowed establishing the power generated by each fuel, thereby, obtaining a comparison criterion with which working conditions that allowed testing for each of the mixtures were established; hence, determining fuel consumption and measuring combustion gases. The results of the above processes allowed 
comparing the characteristics of biodiesel from castor oil and sunflower oil against conventional diesel (fossil).

\subsection{Sunflower Oil}

\subsubsection{Phase One}

The process began by mixing methanol with sodium hydroxide as a catalyst, forming sodium methoxide $\left(\mathrm{Na} \mathrm{CH}_{3} \mathrm{O}-\right)$ in an exothermic reaction and then it was blended with sunflower oil; this process is subdivided into mixture, decantation, and $\mathrm{pH}$ stabilization [10] [11].

- Mixing: The methoxide was mixed with sunflower oil at $40{ }^{\circ} \mathrm{C}$, shaking it to cause the partition of the fatty acid into Glycerin and ester chains, which then reacted with the methanol giving rise to biodiesel [12].

- Decanting: This mixture was recovered and separated in phases by decanting to separate the glycerol $\left(\mathrm{C}_{3} \mathrm{H}_{8} \mathrm{O}_{3}\right)$. After 24 hours the glycerol was extracted and could be recycled, while biodiesel could be washed, if necessary.

- Stabilization of pH: Finally the biodiesel was washed with caustic water $\left(\mathrm{NaOH}+\mathrm{H}_{2} \mathrm{O}\right)$ to remove residual glycerol and impurities, neutralizing the $\mathrm{pH}$.

\subsubsection{Phase Two}

In this phase, laboratory tests were performed showing that the oil had similar properties as those of traditional diesel fuel, minimizing the risk of negative effects on the engine and ensuring that biofuel can be used in any diesel engine [13] [14] [15].

\section{Results}

\subsection{Castor Oil Infrared Analysis}

Regarding the verification of the chemical processes of the transesterification, infrared analysis of castor oil and biodiesel was performed. Comparing the two spectra (Figure 1 (a) and (b)), certain characteristics of the esters were observed by means of the transmission bands, which - between the $1220 \mathrm{~cm}-1$ and 1125 cm-1 wavelength - showed typical ester bands. Analytical results of the infrared of castor oil biodiesel and of the pure castor oil used as a pattern show that the castor oil transesterification process took place correctly, allowing this experimental mechanism to be carried out for the final production of biodiesel. After this procedure, 61 of biodiesel were produced, as well as $\mathrm{NaOH}$, methanol, and glycerol (Table 1).

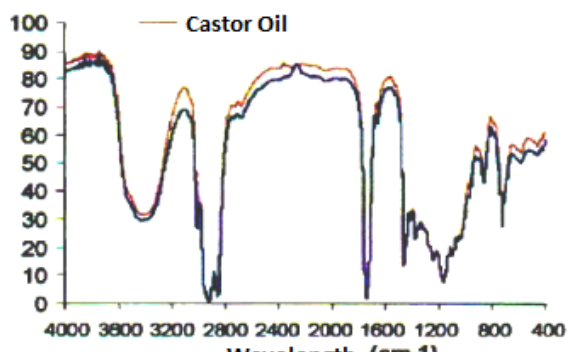
Wavelength (cm-1)

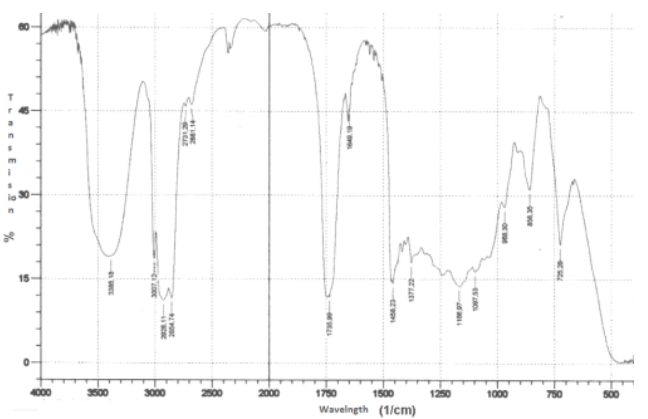

Figure 1. Infrared of: a) castor oil biodiesel b) sunflower oil.

Table 1. Supplies and reagents for biodiesel obtained.

\begin{tabular}{|c|c|c|c|}
\hline Methanol & NAOH & Biodiesel & Glycerine \\
\hline $1500 \mathrm{ml}$ & $18 \mathrm{~g}$ & $6000 \mathrm{ml}$ & $390 \mathrm{ml}$ \\
\hline
\end{tabular}

\subsection{Density of Castor and Sunflower Oils}

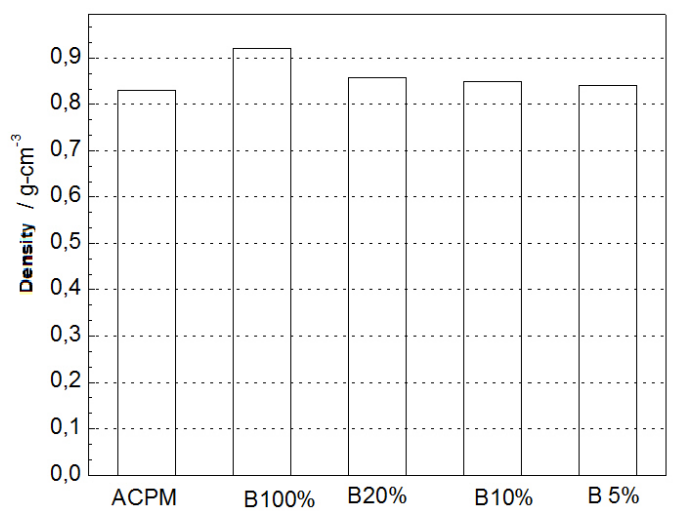

Figure 2. Diagram of the density variation between ACPM and blends of biofuels.

The density of pure biodiesel and the blends (ACPM with Castor biodiesel) presented an increase in density because biodiesel density is higher and when mixed with the ACPM it gradually increases depending on the mixture (Figure 2). The density in the B5 mixture 


\section{TECCIENCIA}

increased by $1.44 \%$, in the B 10 by $2.04 \%$, in the B20 by $2.88 \%$, and in the B100 by $11.04 \%$, compared to ACPM.

With respect to the sunflower biodiesel, it was proven that it presents suitable chemical and physical stability since it has a density of 884.0 $\mathrm{kg} / \mathrm{m}^{3}$, compared with the pattern established in the NTC 100/4 technical standard (between 860 - $\left.900 \mathrm{~kg} / \mathrm{m}^{3}\right)$ [16] and the ACPM fossil $(850$ $\mathrm{kg} / \mathrm{m}^{3}$ ). To measure this property, the room temperature used was $18^{\circ} \mathrm{C}$.

\subsection{Castor Oil and Sunflower Oil Viscosity}

Viscosity was affected by the density of the castor oil blends and, therefore, caused a similar increase as in the density; the viscosity of the pure biodiesel exceeded ACPM viscosity by almost twofold. The B5 blend increased by $19 \%$, $\mathrm{B} 10$ by $22.29 \%, \mathrm{~B} 20$ by $42.6 \%$, and $\mathrm{B} 100$ increased $172 \%$, compared to fossil diesel fuel ACPM (Figure 3). Increased viscosity generated better lubrication in the mechanical parts of the engine, thereby, ensuring its integrity. However, the results of this property can potentially cause a problem because the values are so high that it is possible to have complications in the fuel injectors of the diesel engine; for this reason, it is not advisable to consider blends with more than $20 \%$ biodiesel (B20).

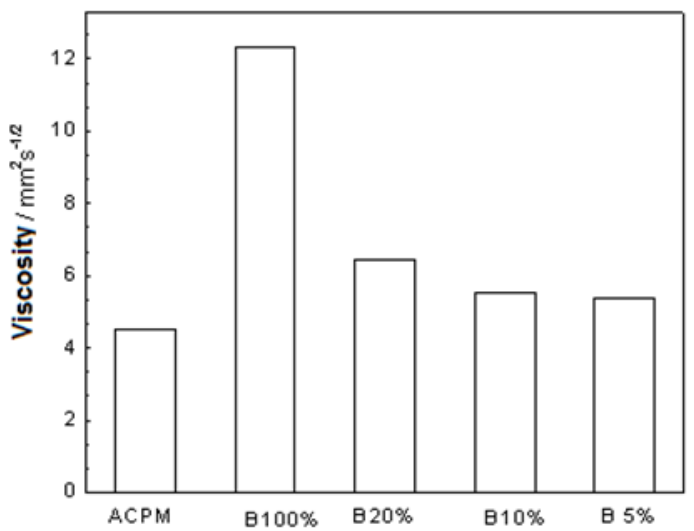

Figure 3. Diagram of viscosity of castor biofuels

With regards to sunflower oil, the result of kinematic viscosity taken at $40{ }^{\circ} \mathrm{C}$ meets the required specification, $1.9-6.0 \mathrm{~mm}^{2} / \mathrm{s} \mathrm{[4]} \mathrm{and} \mathrm{the}$ sunflower oil biodiesel has $5.03 \mathrm{~mm}^{2} / \mathrm{s}$, although this is approximately two times greater than that of diesel fuel $2.36 \mathrm{~mm}^{2} / \mathrm{s}$. The results for sunflower biofuel ensure adequate injection of the blend to the engine and maintain a proper operation of the injection system components; using the $\mathrm{B} 100 \%$ mixture is not encouraged because it requires a relatively powerful system to inject fuel into the engine chambers, making it necessary to modify the engine pumping system.

\subsection{Calorific value of castor and sunflower oil}

The calorific value of the castor biofuel blends was determined by using a calorimetric pump, these values were compared with those of fossil diesel fuel (ACPM), generating a 2.23\% decrease in the B5 blend, $6.89 \%$ in the B10, $11.37 \%$ in the B20, and $18 \%$ in the B100 blend (Figure 4). The calorific decrease is because the calorific value of vegetable oils is lower than that of ACPM. Moreover, the value shown in mixture B5 generates the best performance with respect to engine power, as opposed to the $100 \%$ blend due to the drop in calorific value.

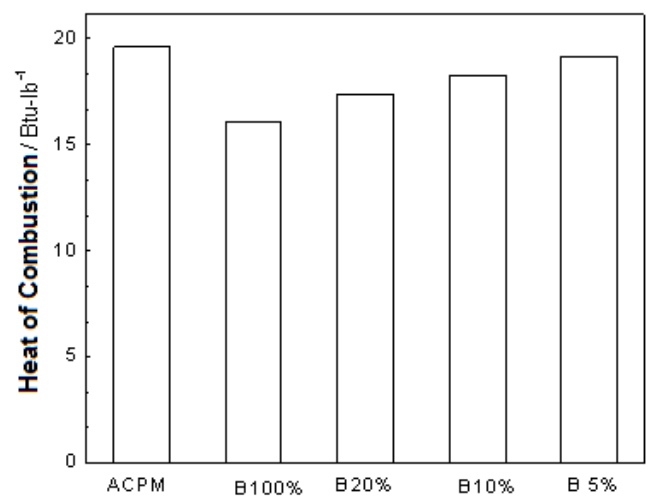

Figure 4. Diagram of combustion heat of castor oil biofuel

The results of biodiesel calorific value from sunflower were obtained through two tests in the calorimetric pump. By following the procedure developed by the manufacturer, ensuring an almost perfect adiabatic process, all variables were controlled and the necessary corrections were also made to ensure the repeatability of the data; the data obtained were 14621.6571 Btu/lb and $19700 \mathrm{Btu} / \mathrm{lb}$ for the castor oil, being very close to the values studied by other authors [17].

\subsection{Emissions Analysis of Castor and Sunflower Oil}

With respect to the emissions analysis presented in Figure 5 ( $a$ and $b$ ), these were divided into $\mathrm{CO}$ (carbon monoxide), $\mathrm{CO}_{2}$ (carbon dioxide), $\mathrm{SO}$ (sulfur oxide), and $\mathrm{HC}$ (hydrocarbons). For the $\mathrm{CO}$, there was a reduction of $25 \%$, while the $\mathrm{CO}_{2}$ in the B5 blend decreased by $11.47 \%$, by $15.20 \%$ in the B10 blend, and $19.19 \%$ in the B20; these results indicate that the reduction percentage is related to the amount of biodiesel used in the ACPM blend. For the $\mathrm{CO}_{2}$ comparison to diesel 


\section{TECCIENCIA}

and the blends under the NTC 100/04 standard, responses were observed to be similar to the one obtained in the carbon monoxide. This result of $\mathrm{CO}$ and $\mathrm{CO}_{2}$ is favorable because it indicates that the fuel blends are cleaner than pure diesel $(100 \%)$ from fossil origin [18].
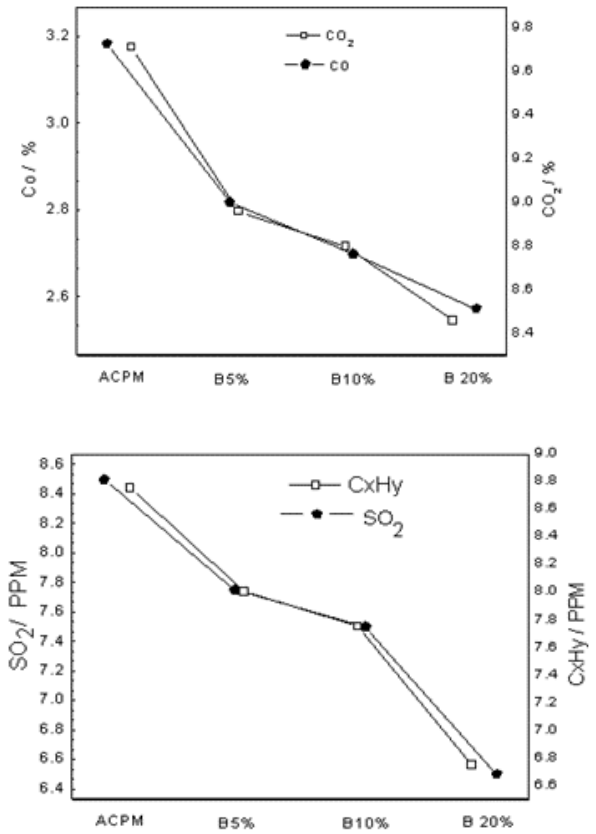

Figure 5. a) Diagram of $\mathrm{CO}_{2}$ and $\mathrm{CO}$ emissions. b) Diagram of $\mathrm{C}_{\mathrm{x}} \mathrm{H}$ and $\mathrm{SO}_{2}$ emissions.

For emissions analysis of sunflower oil, measurements were made in a vacuum turbocharged 1600-cc diesel engine, with commercial diesel fuel, B5 ACPM (5\% blended sunflower biodiesel) and B10 ACPM (10\% biodiesel) in order to find changes in $\mathrm{CO}, \mathrm{CO}_{2}$, $\mathrm{SO}_{\mathrm{x}}, \mathrm{C}_{\mathrm{x}} \mathrm{H}_{\mathrm{y}}$, and $\mathrm{O}_{2}$. The procedure consisted of performing emission measurements at different engine speeds, beginning at idle $(850 \mathrm{rpm})$ and

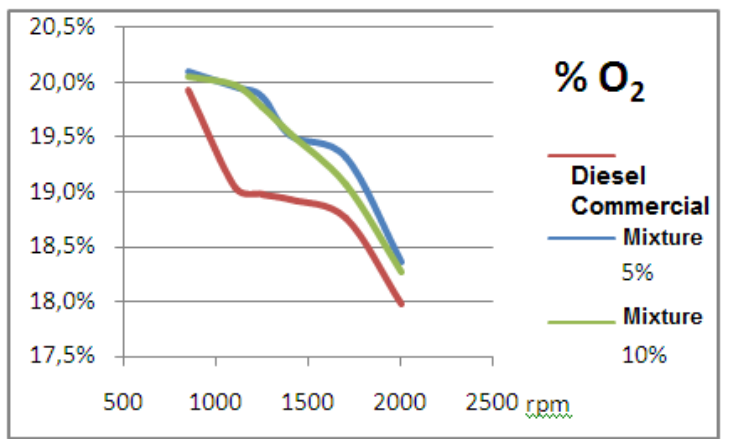

increasing to $1100,1250,1400,1700$, and 2000 rpm. Regimes were controlled with an

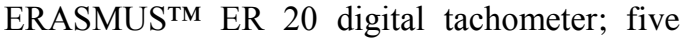
measurements of 15 registries for each RPM regime were recorded. The equipment used to measure combustion gases was a TESTO ${ }^{\mathrm{TM}} 350$ 14 [14].

Emissions measurements are presented as a percentage of $\mathrm{O}_{2}$ and $\mathrm{CO}_{2}$ (Figure 6) respectively; it can be seen that the percentage of $\mathrm{CO}_{2}$ reduction is due mainly to low speed revolutions, however, at higher RPM regimes, values tend to converge when relating to the percentage of $\mathrm{O}_{2}$, indicating that combustion has declined as a result of blending with biodiesel.

The results of measurements of gas emissions are given in parts per million (ppm) for $\mathrm{CO} ; \mathrm{SO}_{\mathrm{x}}$, $\mathrm{C}_{\mathrm{x}} \mathrm{H}_{\mathrm{y}}$ are shown in Figure 7 (a and b), respectively, where we can see a substantial reduction of $\mathrm{CO}$ at low RPMs in the biodiesel blends compared to fossil diesel fuel. With respect to the presence of $\mathrm{SO}_{\mathrm{x}}$, reduction percentages can be observed similar to the biodiesel blends of 5\% and $10 \%$ at low RPMs, and convergence of results at higher RPM regimes.

When Involving the Hydrocarbon ppm " $\mathrm{C}_{\mathrm{x}} \mathrm{H}_{\mathrm{y}}$ " curve (Figure 8), the presence of these hydrocarbons is confirmed at intermediate revolutions in the biodiesel blends; however, at higher RPM regimes, values tend to decrease $\mathrm{CO}$ and increase $\mathrm{CO}_{2}$. Comparing the two biodiesel blends, it can be seen that the $10 \%$ blend would have a slightly better performance in the various gas measurement results, becoming apparent that the amount of $\mathrm{CO}$ and hydrocarbons diminish, thereby, improving fuel combustion with biodiesel.

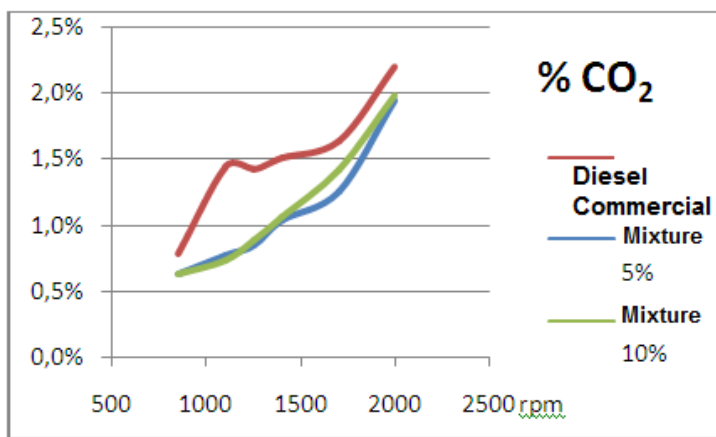

Figure 6. Gas combustion curve a) oxygen, b) carbon dioxide 


\section{TECCIENCIA}
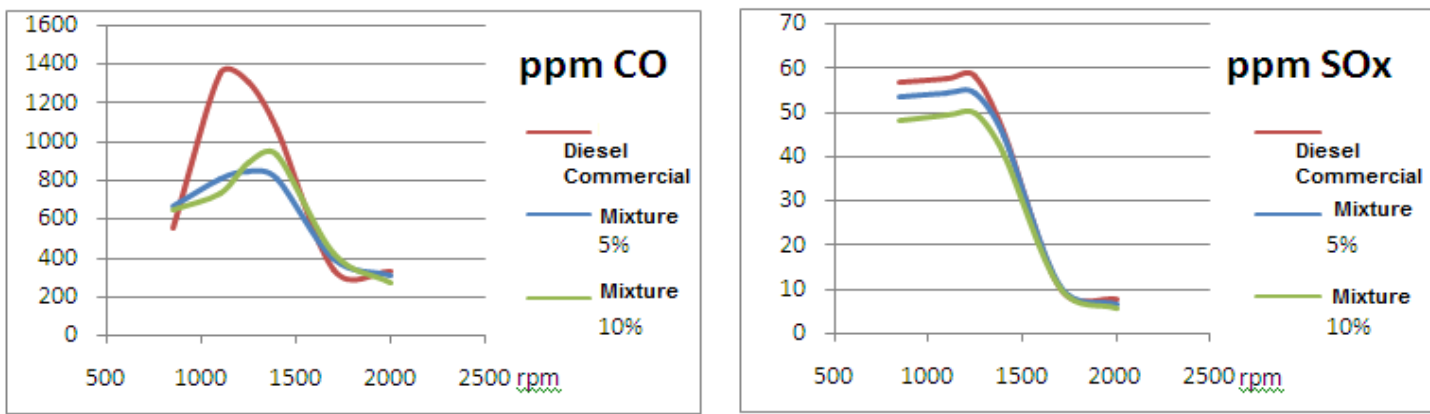

Figure 7. Gas Combustion Curve a) Carbon monoxide, b) Sulfur Oxides.

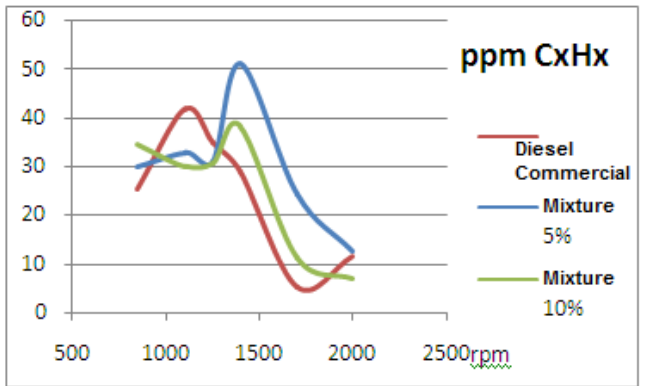

Figure 8. ppm hydrocarbon emissions curve

Comparing the two blends of castor and sunflower biodiesel, it is shown that the blend at $10 \%$ would have a slightly better performance. With respect to the presence of $\mathrm{C}_{\mathrm{x}} \mathrm{H}_{\mathrm{y}}$, the $5 \%$ and $10 \%$ blends have a stable performance initially, but at $1250 \mathrm{rpm}$ the blends show a large increase in fossil diesel ppm and with a $5 \%$ blend of biofuels, indicating a reduction in the combustion quality compared to the curve of commercial diesel. At high speeds, greater than $2000 \mathrm{rpm}$, we can see convergence in the values making it clear that these harmful gases are reduced; this has been evaluated in Bogotá - a condition which is one of the factors affecting complete combustion due to the height above sea level $(2600 \mathrm{~m})$.

\section{Conclusions}

The production of biodiesel from castor and sunflower oils is viable because it has adequate yields; in both cases, the compound with the highest value is the $\mathrm{NaOH}$ catalyst concentration, which directly affects fuel efficiency, demonstrating that the lower the catalyst concentration, the more favorable the performance of the mixture becomes.

With respect to the physical-chemical properties, it was found that biofuels and conventional diesel have sufficient similarities so that it can be predicted that negative effects are not potential hazards in any diesel engine. Moreover, the density and viscosity of biofuels have good stability [17].
If the sunflower biofuel blend B100 is used, it would present some problems at low temperature or in cold climates, given that its cloud point is at $3{ }^{\circ} \mathrm{C}$ and the water content could decrease combustion efficiency; additionally, both free glycerin, as well as its sodium and potassium content could form deposits that would cause some wear due to friction or cause oxidation, corrosion and/or deterioration of some components containing rubber or plastics that can be degraded.

The 5\% and $10 \%$ biodiesel blends show a pollutant reduction with respect to commercial diesel in an acceptable amount and according to the requirements of the Colombian Standard Technical Norm ICONTEC NTC 100V04 under Bogotá conditions.

After the two phases of the study, it is concluded that biodiesel made from plant oils (castor and sunflower) is an alternative as a partial substitute for diesel up to a $10 \%$ (B10) blend of biodiesel, where the statistical results obtained in the B5 and B10 blends behave similarly in power and consumption compared to the ACPM of fossil origin. In addition to contributing significantly to the reduction of environmental pollution in accordance with current regulations, they can also be promoted in the energy basket as products of the agro-industrial chain. It is important to take into account that biodiesel does not compete with food for human consumption.

\section{Acknowledgements}

The authors wish to thank Cifuentes Sanabria Yuli Paola, UMNG Research Assistant industrial engineering program. We extend our appreciation to Gonzalez Barinas Jimmy. 


\section{TECCIENCLA}

\section{References}

[1] A. Corredor, «"Tablero de comando" para la promoción de Biocombustibles en Colombia,» Organización de las Naciones Unidas, Santiago de Chile, 2009.

[2] Grupo de Investigación en Combustibles Alternativos, Energía y Protección del Medio Ambiente, «Comparación de emisiones de motores operados con Petrodiesel y Biodiesel,» Revista Ingenerare, vol. 23, $\mathrm{n}^{\mathrm{o}}$ 1, pp. 13-20, 2009.

[3] Federación Nacional de Cultivadores de Palma de Aceite, «Mercadeo y promoción de mercados Biodiesel,» 2006. [En línea]. Available: http://www.fedepalma.org/biodiesel.htm.

[4] American Society for Testing Materials, «Sec 5 Petroleum products, Lubricants and Fossil fuels,» ASTM International, 2004

[5] G. Hincapié, F. Mondragón y D. López, «Conventional and in situ transesterification of castor seed oil for biodiesel production,» Fuel, vol. 90, n 4 , pp. 1618 1623, 2011.

[6] D. E. Arias Pérez, C. A. Teuta Ramirez y J. Parra Plazas, «Caracterización de las propiedades del biodiesel de girasol bajo la Norma NTC de 100/04 y medición de poder calorífico,» AVANCES Investigación en Ingeniería, vol. 8, $\mathrm{n}^{\circ} 2$, pp. 73-80, 2011.

[7] PARR Instrument Company, Manual de la bomba calorimétrica 204M, Illinois, 2000.

[8] J. Goodrum, «Volatility and boiling points of biodiesel from vegetable oils and tallow,» Biomass and Bioenergy, vol. 22, $\mathrm{n}^{\circ} 3$, pp. 205-211, 2002.

[9] C. E. Goering, A. Schwab, M. Daugherty, E. Pryde y A. Heakin, «Fuel Properties of eleven Vegetable Oils,» Transaction of the ASABE, vol. $25, \mathrm{n}^{\circ} 6$, pp. 1472 1477, 1982.
[10] R. Altin, S. Cetinkaya y H. Serdar Yücesu, «The potential of using vegetable oil fuels as fuel for diesel engines,» Energy conversion and Management, vol. $42, \mathrm{n}^{\circ} 5$, pp. 529-538, 2001.

[11] L. L. Sousa, I. L. Lucena y F. A. Fernandes, «Transesterification of castor oil: Effect of the acid value and netutralization of the oil with glycerol,» Fuel Processing Technology, vol. 91, $\mathrm{n}^{\circ}$ 2, pp. 194-196, 2010.

[12] A. Peña y J. Céspedes, Fisicoquímica - Manuel de Laboratorio, Medellín: Universidad de Medellín, 2000.

[13] ICONTEC, «Norma Técnica Colombiana NTC 544 Biodiesel para uso en motores diesel,» ICONTEC, Bogotá D.C., 2006.

[14] Instrumentos y Mediciones Industriales LTDA «Certificado de Calibración, Fecha de Calibración Junio de 2010,» Universidad Libre, Bogotá D.C., 2010

[15] Federación Nacional de Biocombustibles, «Boletines Informativos, 2009-2010,» 2009. [En línea]. Available:

http://www.fedebiocombustibles.com/v2/noticiasfedebiocombustibles-cat-8.htm.

[16] ICONTEC, «Norma Técnica Colombiana DE100/04 Especificaciones para uso de biocombustibles en motores diesel,» ICONTEC, Bogota, 2004.

[17] B. Barnwai y M. Sharma, «Prospect of biodiesel production from vegetable oils in India,» Renewable and Sustainable Energy Reviews, vol. 9, $\mathrm{n}^{\circ} 4$, pp. 363 378, 2005.

[18] A. Benavides, P. Benjumea y V. Pashova, «El, Biodiesel de aceite de higuerilla como combustible alternativo para motores biodiesel,» Dyna, vol. 154, pp. 141-150, 2007. 